\title{
On the Size Distribution of Submicron Aerosols in the North Pacific Air
}

\author{
By Tomoyuki Ito \\ Meteorological Research Institute, 1-1, Nagamine, Yatabe-machi, Tsukuba-gun, \\ Ibaraki-ken, 305, Japan \\ (Manuscript received 7 August 1979, in revised form 7 December 1979)
}

\begin{abstract}
The size distributions of submicron aerosols were measured at Minamitorishima Is. (Marcus Is., $24^{\circ} \mathrm{N}, 154^{\circ} \mathrm{E}$ ) and the Ogasawara islands (Bonin Is., $27^{\circ} \mathrm{N}, 142^{\circ} \mathrm{E}$ ) during two weeks in the autumns of 1975 and 1976 respectively. The purpose of these measurements was to get information about the concentrations and size distributions of aerosols in the North Pacific maritime atmosphere.

To get the continuous records of the size distribution of natural aerosols, we employed the diffusion decay technique and an improved Pollak type condensation nucleus counter. From the set of decay rates of concentration of aerosols passing through the diffusion batteries, the size distribution of aerosol particles with radii between 0.002 and $0.2 \mu \mathrm{m}$ was determined by use of a response matrix method.

The most important finding in the present work is that there is a notable difference in the size distributions and total concentrations of aerosols depending upon the origin of the air mass. In an air mass which has come from the main island of Japan, the total number concentration of aerosols is of the order of 1,000 to $2,000 \mathrm{~cm}^{-3}$ and their size distribution tends to have a narrow range with a main peak between 0.02 and $0.07 \mu \mathrm{m}$ in radius. On the other hand in an air mass of mid-latitude maritime origin, the total number concentration of aerosols is of the order of $250 \mathrm{~cm}^{-3}$, which is comparable to the background concentration in these oceanic regions. The size distribution of aerosols in such an air mass tends to have a rather broad range with a main peak at around $0.02 \mu \mathrm{m}$ and a second peak, though not always detected, at around $0.004 \mu \mathrm{m}$ in radius.

Present results suggest the possibility of the aerosols transported from land affecting the background concentration of the cloud condensation nuclei in the clean oceanic atmosphere.
\end{abstract}

\section{Introduction}

In the study of the aerosol background pollution on the global scale, the essential requirement is a detailed knowledge of the physical and chemical properties of aerosols in a clean atmosphere which is not directly affected by manmade aerosols. One of the most important parameters in the behavior of aerosols is their size distribution. Though a number of investigations have been made so far, our present knowledge of the size distribution of aerosol particles in the clean atmosphere, especially of those with in the radius range below $0.1 \mu \mathrm{m}$, seems to be rather insufficient (Junge et al., 1971; Ohta et al., 1973; Jaenicke, 1974; Misaki et al.,
1975). Therefore more measurements adequate for the determination of size distribution of aerosol particles should be made in the clean atmosphere.

In the autumns of 1975 and 1976 the size distributions of submicron aerosols were measured with the improved Pollak counter and diffusion batteries at Minamitorishima $\left(24^{\circ} 18^{\prime} \mathrm{N}\right.$, $\left.153^{\circ} 58^{\prime} \mathrm{E}\right)$ and Chichijima $\left(27^{\circ} 06^{\prime} \mathrm{N}, 142^{\circ} 11^{\prime} \mathrm{E}\right)$ Islands respectively. Minamitorishima (Marcus) Is. is a small island in the Pacific Ocean $2,000 \mathrm{~km}$ southeast of Tokyo and Chichijima (Bonin) Is. is the most populous of the Ogasawara islands located $1,000 \mathrm{~km}$ south of Tokyo.

In this paper, we will show the results of these measurements. The present work aims to 
find the general pattern of the size distribution of submicron aerosols in the maritime background atmosphere over the North Pacific Ocean and also aims to obtain some information on the size of aerosol particles which are transported from the mainland of Japan by the westerly air flow and dispersed in the atmosphere over this oceanic region.

\section{Method of determination of size distribution}

The principle of the method utilized in the present investigation is basically similar to the diffusion decay technique proposed by Pollak et al. (1957a). When aerosols are subjected to flow through the narrow channels of a diffusion battery, they suffer decay in concentration due to the diffusion of particles to the walls of the channels. The decay rate depends upon the size distribution of aerosols, the length and width of the channels and the flow rate with which the aerosols are sent through the channels. When the aerosol concentrations are measured at the entrance and exit of the channels, at various flow rates, the ratios of these two concentrations give a set of decay data which can be converted to a size distribution by solving an inverse problem. Since the size distribution obtained by this method is very sensitive to the numerical error of observed concentration, a well-designed instrument that can make precise measurement of aerosol concentration is needed. The diagram of the present setup is shown in Fig. 1. The Pollak counter used in the setup has improved portions which make possible continuous automatic measurements of very low aerosol concentration down to several tens of particles $\mathrm{cm}^{-3}$ under various field conditions.

The counter is essentially similar to the 1957 Pollak type photo-electric condensation nucleus counter (Metnieks et al., 1959) with a slightly convergent light pencil (Pollak et al., 1957b) and operated with under-pressure expansion (Pollak et al., 1961). It is distinguished, however, in its fog tube. The four-short-tube ceramic lining of the original fog tube is displaced by a single unit ceramic tube directly jacketed with water; the water has a constant temperature and is flowed periodically so as to maintain the fog tube at constant temperature as well as to keep the entire ceramic lining uniformly wet (Ito, 1976).

In the Pollak counter, the concentration of aerosols is estimated from the extinction of the light beam traversing the fog produced by the adiabatic expansion of the moist aerosol-laden air

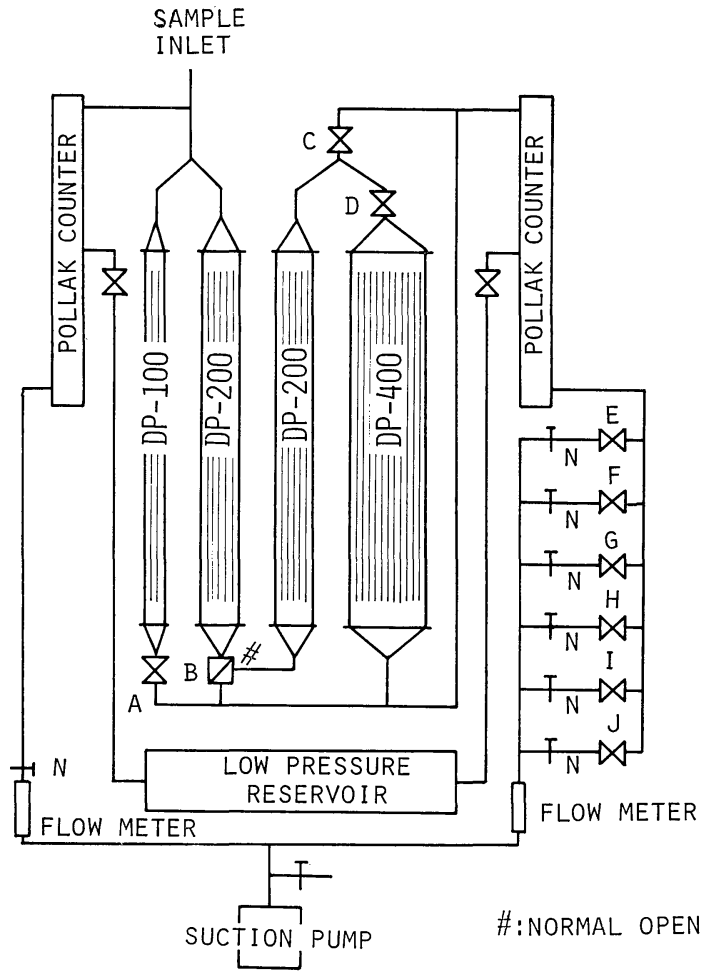

Fig. 1 Setup used in the present work to obtain the diffusional decay data of aerosols in the six decay stages. "A,C, - J" denote one-way valves and "B" a two-way valve. "N"s denote needle valves for adjusting flow rates in each of the six decay stages. "DP-100" denotes the diffusion battery which consists of 100 nickel tubes.

which is sampled into the fog tube. The preconditioning of the temperature and moisture of the aerosol-laden air just before the expansion is an essential requirement for automatic operation under various field conditions for a long time without renewing the calibration. The present counter meets this requirement by use of the improved fog tube mentioned above.

Furthermore for the extinction measurement for very low concentration, say lower than 1,000 particles $\mathrm{cm}^{-3}$, a special technique is employed in order to enhance the sensitivity of the measurement. This is basically similar to the electric compensation method used by Pollak et al. (Pollak et al., 1957c) but improved in its capability of automatic recording. In the present counter, when no fog appears in the fog tube, the photo-electric current is balanced by the compensation current supplied by a mercury battery and therefore zero line is recorded. When 
a fog appears, the consequent decrease in the light intensity is recorded in terms of a deficit of the photo-electric current against the compensation current with the sufficient magnitude of amplification. For reference, the light intensity decrease due to the extinction by an optical filter which is placed over the photo-cell from time to time is also recorded in the same manner when no fog is in the fog tube. The extinction by fog which is related to the aerosol concentration is determined from the photo-electric current deficit due to fog formation by comparing it with the deficit due to the optical filter with a known extinction value, say $8 \%$ for the light beam of the present counter. Thus the reliable values of concentrations can be obtained down to several tens of particles $\mathrm{cm}^{-3}$.

The diffusion battery is a bundle of 100,200 or 400 nickel tubes of $2.0 \mathrm{~mm}$ inside diameter and $1.0 \mathrm{~m}$ length encased in a $1.2 \mathrm{~m}$ length brass pipe. The spaces between the small tubes are filled with plastic binding agent so that the aerosols pass only through the tubes. In a previous work (Ohta et al., 1973), a set of decay data was obtained by the method using one single diffusion battery (200 Ni-tubes) with the flow rates varying from 0.2 to 5.0 liters per minute. In that case, some difficulty was experienced in controlling the flow rate precisely over such a wide range of flow rate in automatic operation. Therefore, in the present work, the combinations of batteries and flow rates shown in Table 1 are used to obtain a set of diffusional decay data of aerosols of six stages.

In the present setup, two identical Pollak counters are operated simultaneously: one for the

Table 1. The combinations of the diffusion batteries and the flow rates to obtain a set of decay data for the determination of size distribution of submicron aerosols. DP100 is a bundle of 100 thin tubes. The symbol " + " means connecting the batteries in series. The notations of valves are the same as in Fig. 1.

\begin{tabular}{cccl}
\hline $\begin{array}{c}\text { Decay } \\
\text { stage }\end{array}$ & $\begin{array}{c}\text { Operated } \\
\text { valves }\end{array}$ & $\begin{array}{c}\text { Flow } \\
\text { rate }\end{array}$ & \multicolumn{1}{c}{$\begin{array}{c}\text { Diffusion } \\
\text { batteries }\end{array}$} \\
\hline 1 & A,E & $4^{*}$ & DP100 \\
2 & A,F & 2 & DP100 \\
3 & B,G & 2 & DP200 \\
4 & C,H & 2 & DP200+DP200 \\
5 & D,I & 2 & DP200+DP200+DP400 \\
6 & D,J & 1 & DP200+DP200+DP400
\end{tabular}

* liters per minute measurement of the concentration at the entrance of the diffusion batteries and the other for that at the exit. At the exit of the diffusion batteries, the concentration of aerosols which have decayed at each of the six decay stages is measured successively. The entire measuring procedure is fully automated with a five-minute performance cycle. Thus for every 30 min., a set of decay data in six stages and six values of the total aerosol concentration can be obtained.

From the set of decay data, the size distribution of aerosol particles with radii between 0.002 and $0.2 \mu \mathrm{m}$ is determined by use of the response matrix method described by Ikebe (1972). The details of the procedure of computation are given in the appendix.

Fig. 2 shows an example of the time variation of the size distribution thus obtained. The data were obtained at Chichijima Is. In the upper part of Fig. 2 the total aerosol concentration (concentration at the entrance of the diffusion battery) are shown by a line of fine dots. Successive measurements of the six decay stages (concentrations at the exit of the diffusion battery) are shown by six dash-dot lines in such a manner that the uppermost line is for the first decay stage, the lowest for the sixth. From these data, the size distributions of aerosol particles are evaluated for the set of decay data of every 30 min. With the present computation scheme the spectral densities of size distribution can be obtained for the 14 radius values which divide the radius range between 0.002 and $0.2 \mu \mathrm{m}$ in logarithmically equal interval. With these spectral densities corresponding radius-time squares in the lower figure of Fig. 2 were filled. Instead of the values thus put in, the contour lines of spectral density drawn on the basis of them are presented in the lower figure of Fig. 2. In this figure, which shows the time variation of the size distribution of aerosols, it can be seen that the gradual decrease of total aerosol concentration is accompanied by the gradual loss of particles larger than $0.7 \mu \mathrm{m}$ in radii.

\section{Results and discussion}

The decay measurements of aerosol concentrations with the present setup were made almost continuously throughout the two observation periods: from 19 October to 2 November of 1975 at Minamitorishima Is. and from 30 October to 12 November of 1976 at Chichijima Is.

In the continuous records of total aerosol concentrations obtained every five minutes during 


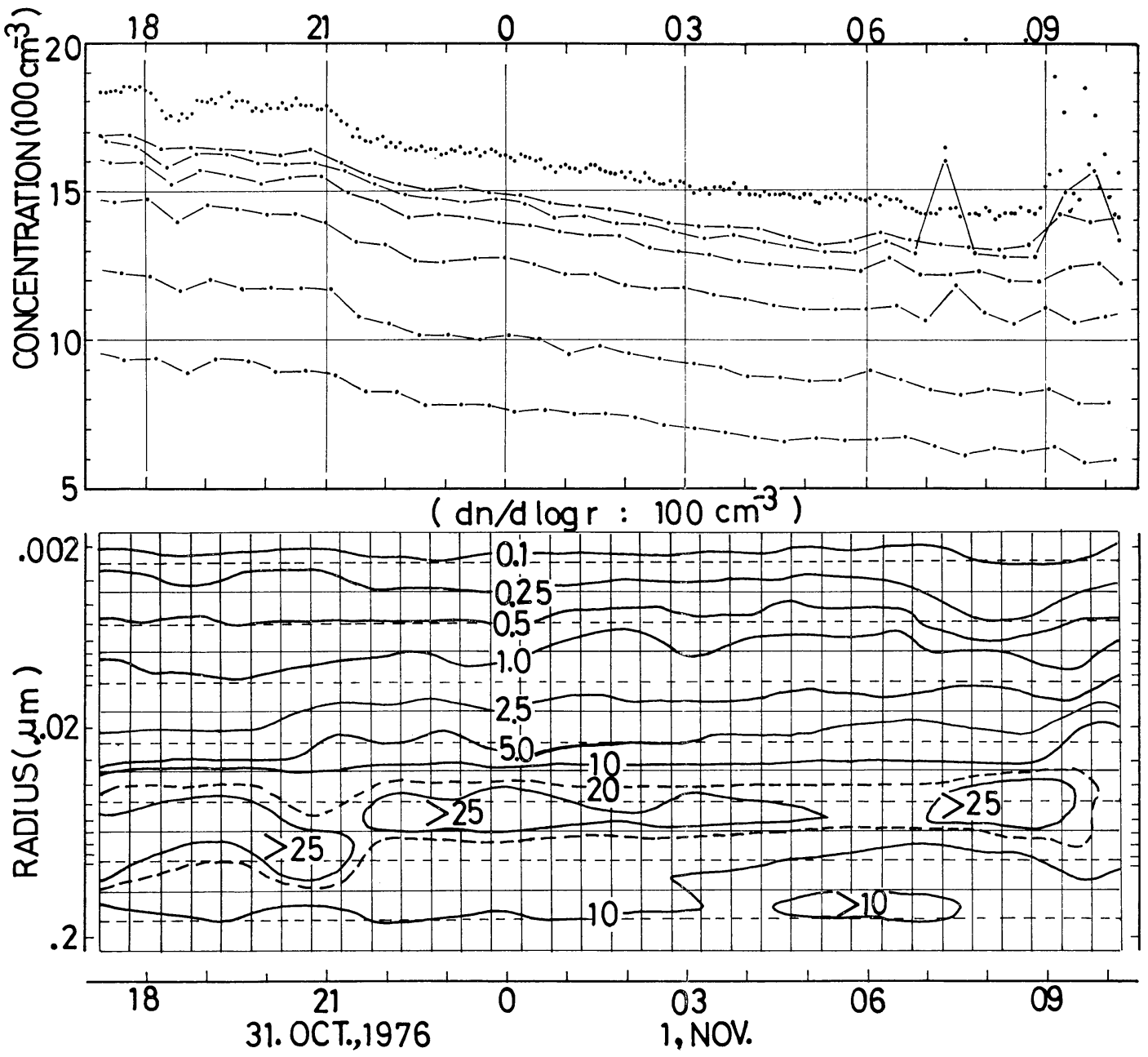

TIME $\rightarrow$

Fig. 2 Continuous records of decay measurement and time variation of size distribution at Chichijima Is. In the upper figure, the total aerosol concentrations observed every five minutes are shown by fine-dotted line. Successive measurements of decayed concentrations at six decay stages are shown by six dash-dot lines in such a manner that the uppermost dash-dot line is for the first stage, the lowest line for the sixth. The lowest figure shows the time variation of aerosol size distribution estimated from the data shown in the upper figure. The curves in the figure are contour lines of spectral density values $(d n / d \operatorname{logr})$ on the radius-time plane and the numerals are spectral densities $\left(\times 100 \mathrm{~cm}^{-3}\right)$.

the observations, the time variation of concentration can be classified roughly into three types: TYPE-I, concentrations with a large random fluctuation; TYPE-II, relatively high concentrations with a very small random fluctuation as shown in Fig. 2; and TYPE-III, low concentrations with a very small random fluctuation. These three types were seen at either Island. In Fig. 3 are shown the three types of time variation which are seen in the data of Minamitorishima Is.

On the basis of the records of surface wind at the weather station in each Island, it was confirmed that the large random fluctuation in the concentrations (TYPE-I) was due to the local sources of contamination in the island. On the other hand, the very small random fluctuation of aerosol concentrations (TYPE-II, III) indicates that the concentration of aerosols was not 

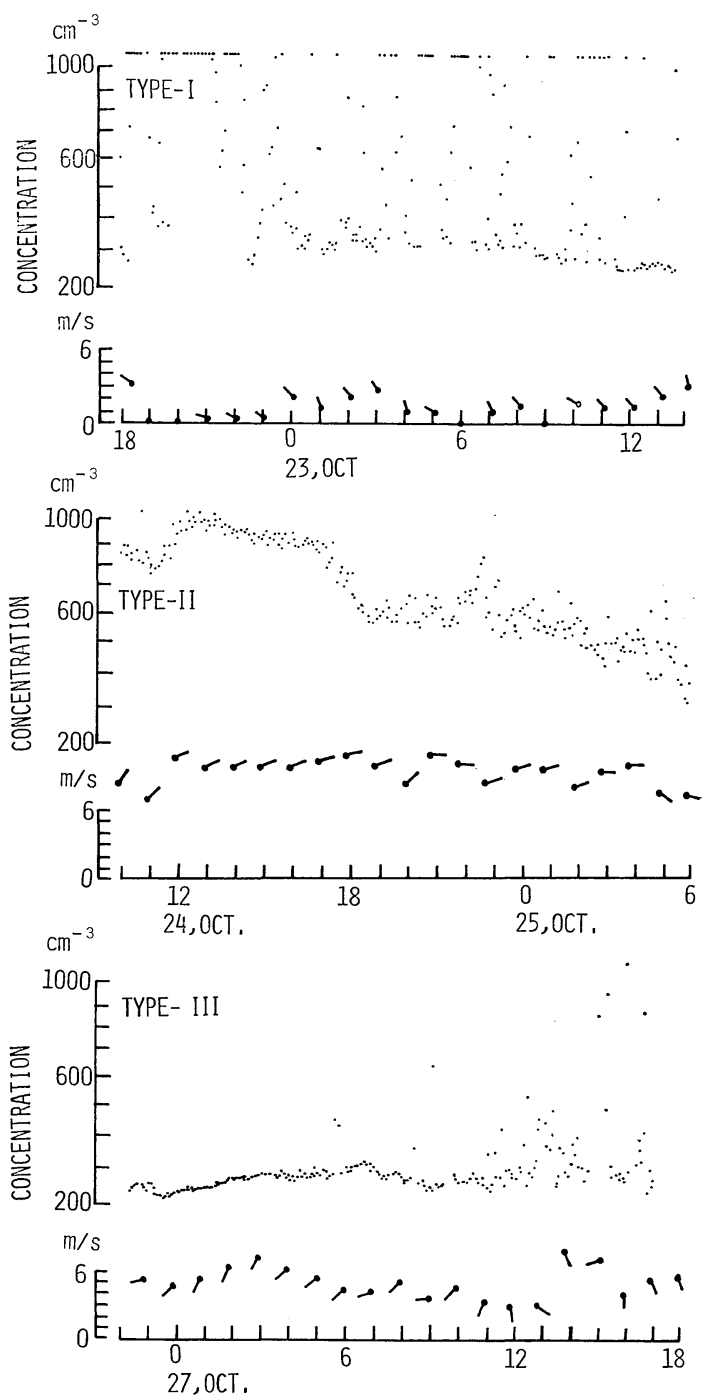

Fig. 3 The three types of concentration records at Minamitorishima Is. The wind velocity and direction are also shown by a series of solid circles with dashes. The wind blows toward the solid circle.

disturbed by the local contamination but was well mixed during the history of the accompanying air mass. The lowest concentration in such undisturbed data (TYPE-III) was of the order of a few hundred particles $\mathrm{cm}^{-3}$, which was comparable to the background concentration in this oceanic region (Ohta et al., 1974), and the highest (TYPE-II) was about 1,000 particles $\mathrm{cm}^{-3}$ at Minamitorishima Is. and 2,000 particles $\mathrm{cm}^{-3}$ at Chichijima Is. According to the analysis of the trajectories of the air mass which were traced back for three days on surface weather maps prepared at intervals of twelve hours, the phenomenon of TYPE-II occurred always in an air mass having a trajectory which extended toward the mainland of Japan, while the air mass of TYPE-III had a trajectory extending to the mid-Pacific. For example, at Minamitorishima Is. in the period when the high concentrations of TYPE-II were observed, say 24-25 October (see the uppermost figure in Fig. 4), the air mass. trajectories extended toward Japan (see the lowest figure in Fig. 4), while in the other periods, 19-23 October and 26 October-3 November, the concentrations were low and the air mass trajectories extended toward the midPacific. Fig. 5 shows similar figures for the observations at Chichijima Is. Therefore, it seems reasonable to regard the air mass associated with TYPE-II as an air mass of land origin and the air mass with TYPE-III as one of mid-latitude maritime origin.

In order to show the representative size distribution of aerosols in air masses prevailing in these oceanic regions, the successive series of size spectra determined every $30 \mathrm{~min}$. are averaged for each of the periods when the total aerosol concentrations are almost constant. The results are shown in Fig. 6. A size spectrum obtained for the outdoor air at our laboratory in Tokyo is also shown in Fig. 6 as an example of urban aerosol situation.

According to the above classification of air masses, the size spectra for the total concentration $N=320 \mathrm{~cm}^{-3}$ (curve $D$ ) at Minamitorishima Is. and for $N=280 \mathrm{~cm}^{-3}$ (curve $H$ ) at Chichijima Is. in Fig. 6 are considered as the size spectra of aerosol particles in air masses of midlatitude maritime origin (TYPE-III) and the others are of land origin (TYPE-II).

For the air mass of land origin, the loss of small particles was notable in comparison with the urban aerosol size spectrum (curve $A$ ). The loss of small particles was remarkable for the size spectra obtained at Chichijima Is., where almost all particles carried by the air mass of land origin have radii larger than $0.02 \mu \mathrm{m}$. This preferential loss of small particles may be regarded as a reflection of the size dependence of the residence time of atmospheric aerosols, as maintained by Misaki et al. (1975) on their experiments aboard an observation ship. According to Twomey (1965), most natural cloud nuclei tend to fall in the $0.01-0.1 \mu \mathrm{m}$ range rather than in Junge's "large particle" category. Therefore, if the particles in the air mass of land origin, like 

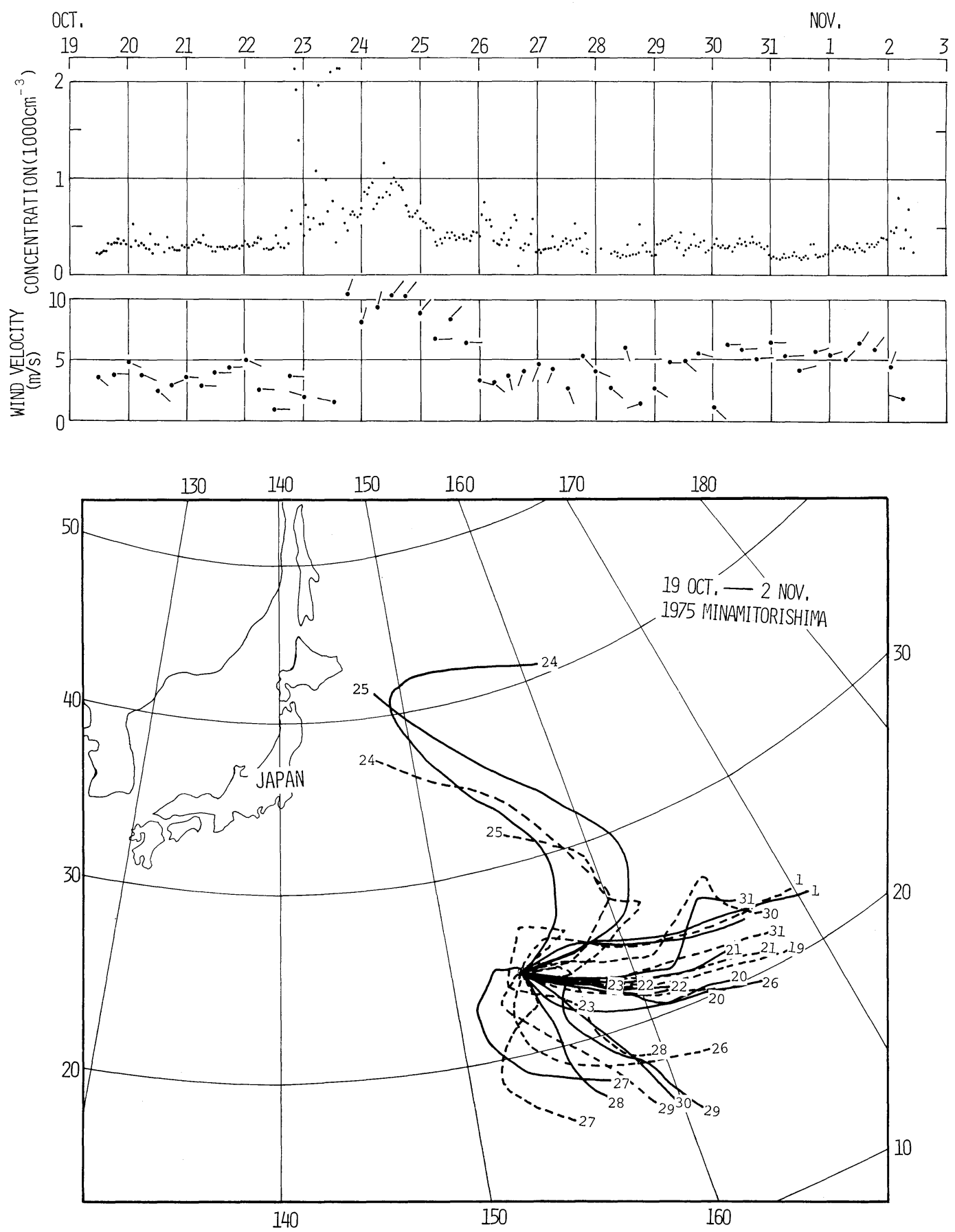

Fig. 4 Comparison of air mass trajectory and aerosol concentration in the air mass for the period 19 Oct.-2 Nov., 1975, at Minamitorishima Is. The upper figure shows the time change of the hourly average of aerosol concentration. The middle figure shows the time change of wind velocity and direction, in which the wind blows toward the solid circle. The bottom figure shows the air mass trajectories which were traced back for three days on the surface weather maps at intervals of twelve hours. The numeral at the end of each trajectory shows the date when the air mass came over the island. 

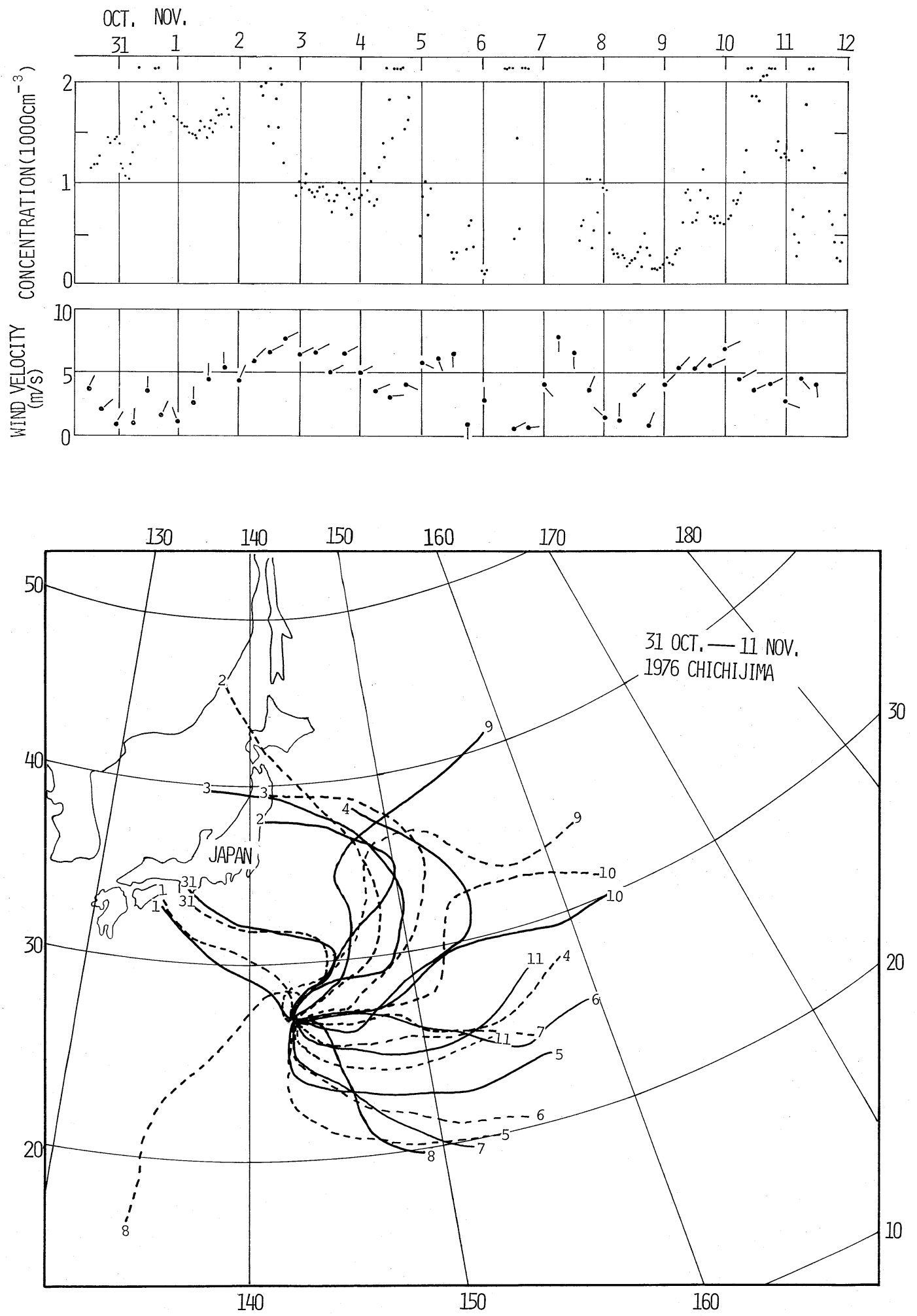

Fig. 5 Comparison of air mass trajectory and aerosol concentration in the air mass for the period 31 Oct.-11 Nov., 1976, at Chichijima Is.; otherwise the same as Fig. 4. 


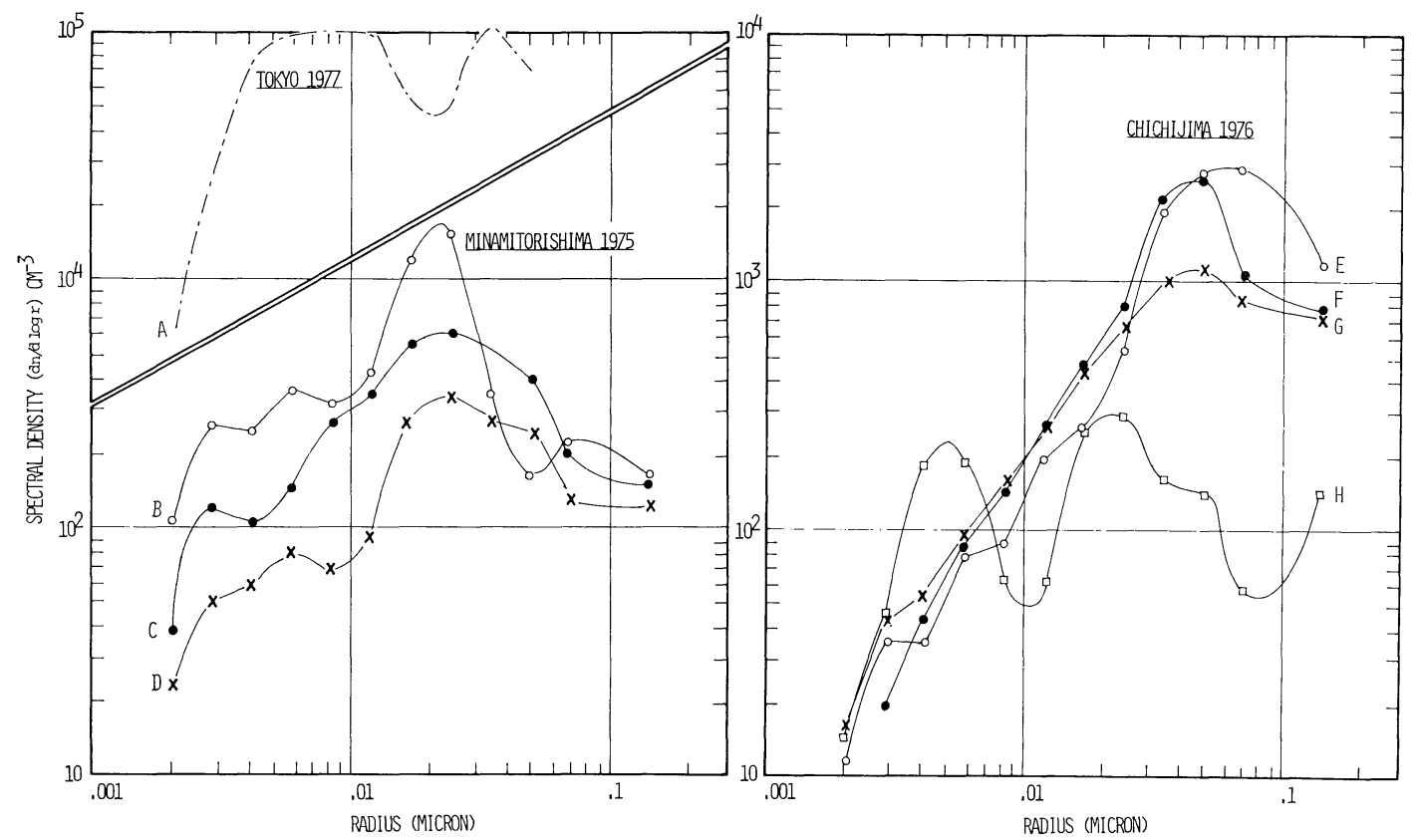

Fig. 6 The representative size spectra of aerosol particles in various air masses over the North Pacific Ocean. The left figure is for Minamitorishima 1975; curve $\mathrm{B},(\mathrm{O}) N=$

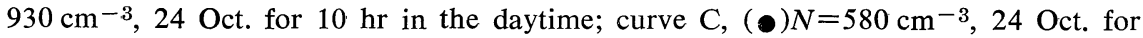
$3 \mathrm{hr}$ including midnight; curve $\mathrm{D},(\times) N=320 \mathrm{~cm}^{-3}, 21$ Oct. for $12 \mathrm{hr}$ day and night; curve A, (dash-dot line) $N=99000 \mathrm{~cm}^{-3}, 21 \mathrm{Mar}$. for $2 \mathrm{hr}$ in the evening in Tokyo. The right figure is for Chichijima 1976; curve $\mathrm{E},(\mathrm{O}) N=1800 \mathrm{~cm}^{-3}, 31$ Oct. for $4 \mathrm{hr}$ at night; curve $\mathrm{F}$, (๑) $N=1500 \mathrm{~cm}^{-3}, 1$ Oct. for $4 \mathrm{hr}$ in the morning; curve $\mathrm{G},(\times) N=1060 \mathrm{~cm}^{-3}, 31$ Oct. for $2 \mathrm{hr}$ in the morning; curve $\mathrm{H},(\square) N=$ $280 \mathrm{~cm}^{-3}, 10 \mathrm{Nov}$. for $2 \mathrm{hr}$ in the morning.

those measured in the present observation, are composed of water soluble matter, they affect the background concentration of the cloud condensation nuclei in the atmosphere over this oceanic region. The present results also show that there is a difference in size spectra even though the total concentrations are nearly equal. For example, it is the case of size spectra of $N=930 \mathrm{~cm}^{-3}$ (curve $B$ ) at Minamitorishima Is. and that of $N=1,060 \mathrm{~cm}^{-3}$ (curve $G$ ) at Chichijima Is. No satisfactory explanation of this fact has been given as yet.

On the other hand, in the air mass of midlatitude maritime origin the size spectra obtained both at Minamitorishima Is. and Chichijima Is. (curve $D$ and $H$ ) had a rather broad shape with a main peak at around $0.02 \mu \mathrm{m}$. The spectrum at Chichijima Is. had an additional second peak around the radius of $0.004 \mu \mathrm{m}$. This second peak may suggest the production of aerosol particles less than $0.01 \mu \mathrm{m}$ in radius in the clean maritime atmosphere, as discussed by Junge (1972). It is important to note, however, that the second peak did not always appear in the present results. Nor has it been found in the previous results obtained on board in the same oceanic region (Ohta et al., 1973; Misaki et al., 1975). Therefore, such small particles in this part of the oceanic atmosphere, if they do exist, seem to require some special conditions for their occurrence.

\section{Summary and conclusion}

The present results based on the measurements of the size distributions of submicron aerosols in the atmosphere over the remote islands in the North Pacific Ocean 1,000-2,000 km away from Japan are summarized as follows.

The most important finding in the present work is that there is a notable difference in the size spectra and total concentrations of aerosols depending upon the origin of the air mass which is determined on the basis of air mass trajectory analysis.

In an air mass which has come from the mainland of Japan, the total concentration of aerosols 
was of the order of 1,000 to 2,000 particles $\mathrm{cm}^{-3}$. In such an air mass, the size distributions of aerosols tend to have a main peak between 0.02 and $0.07 \mu \mathrm{m}$ in radius and the concentration of particles smaller than the peak radius decreases sharply toward the smallest radius.

On the other hand, in an air mass of midlatitude maritime origin, the total concentration is of the order of 200 to 300 particles $\mathrm{cm}^{-3}$, which is comparable to the background concentration representative of the North Pacific maritime atmosphere. The size distribution of aerosols in such an air mass tends to be rather broad with a main peak around $0.02 \mu \mathrm{m}$ and a second peak, though not always detected, around $0.004 \mu \mathrm{m}$ in radius.

The present results suggest the possibility that the aerosols transported by the air from over the land could affect the background concentration of the cloud condensation nuclei in the clean oceanic atmosphere because most of the aerosols in an air mass of land origin have a large number of particles in the same size ranges as natural cloud condensation nuclei.

\section{Acknowledgements}

The author wishes to express his deep thanks to Dr. M. Misaki, Chief of the Upper Atmosphere Physics Division of the Meteorological Research Institute, for helpful discussions and suggestions. He is also deeply indebted to Prof. A. Ono of Nagoya University for his encouragement during the course of this work. This work was made as a part of the special research project "Study on MRI Monitoring System for Global Background Air Pollution of Particular Significance to Weather and Climate". The author is deeply indebted to Dr. S. Ohta, former leader of this project for introducing him to this field of work and giving him the opportunity to start the present work. His thanks are also due to Dr. H. Saito, successor to Dr. S. Ohta as leader of the project, and all the members of MRI Special Research Group on the project for their kind cooperation in the field work.

\section{Appendix}

The aerosol concentration measured at the exit of a diffusion battery is expressed as follow:

$$
Z(Q)=\int_{0}^{\infty} P(Q, D) f(D) d D,
$$

where $D$ is the diffusion coefficient of particles and $Q$ the flow rate of aerosols passing through the battery. In eq. (1), $f(D)$ is called the spectral density function of aerosol size distribution, or simply the distribution function. $P(Q, D)$ is the penetration function for the particles with diffusion coefficient $D$ passing through the battery with flow rate $Q$. An empirical formula given by Ingham (1975) is employed as an expression $P(Q, D)$ for the circular tubes. That is

$$
\begin{aligned}
& P(Q, D) \equiv F(\Delta)=0.819 \exp (-14.63 \Delta) \\
& \quad+0.0976 \exp (-89.22 \Delta) \\
& \quad+0.0325 \exp (-228 \Delta) \\
& \quad+0.0509 \exp \left(-125.9 \Delta^{2 / 3}\right) \\
& \Delta \equiv D L / 4 U R^{2},
\end{aligned}
$$

where $D=$ diffusion coefficient, $L=$ length of the circular tube, $R=$ inner radius of the tube and $U=$ mean flow velocity in the tube. Ingham's formula has the advantage that the single simple formula provides fairly accurate values of penetration for a wide range of $\Delta$-values. If more precise values are needed we should use two asymptotic formulae obtained by Gormly and Kenedy (Ingham 1975), each of which is applicable for large $\Delta$-values and small $\Delta$-values respectively. In the present work, the integral equation (1) is treated in the following matrix form:

$$
\left\{Z_{i}\right\}=\left[R_{i j}\right] \times\left\{f_{j}\right\} \quad(i, j=0,1,2, \cdots, n) .
$$

Here, $Z_{i}$ is a concentration measured at the exit of the battery at the $i$-th decay stage. $Z_{0}$ is for the zeroth decay stage; that is, the concentration at the entrance of the battery. $f_{j}$ is the number of particles that fall into the $j$-th size subrange; that is,

$$
f_{j}=\int_{D_{j}-\alpha_{j}}^{D_{j}+\beta_{j}} f(D) d D,
$$

$\alpha_{j}+\beta_{j}=$ the width of $j$-th subrange. $R_{i j}$, an element of the response matrix, is the penetration of particles with diffusion coefficient $D_{j}$ at the $i$-th decay stage. Naturally, $R_{0 j}=1$.

By solving the set of linear equations (3), we can estimate $\left\{f_{j}\right\}$ and also $f(D)$ from observed values of $\left\{Z_{i}\right\}$. According to Ikebe (1972), for obtaining a plausible solution of eq. (3) the practically useful method is an iterative technique involving successive approximation of $\left\{f_{j}\right\}$. In this method, the $N$-th order approximation for $f_{j}$, denoted by $f_{j}{ }^{N}$, is expressed as follows:

$$
\begin{aligned}
& f_{j}^{N}=f_{j}^{N-1} \times Z_{j} \mathrm{obs} / Z_{j}^{N-1} \quad(j=0,1,2, \cdots, n) \\
& Z_{i}^{N-1}=\sum_{j=0}^{n}\left(R_{i j} \times f_{j}^{N-1}\right) \quad(i=0,1,2, \cdots, n),
\end{aligned}
$$


Table 2. Response matrixes used in the present work.

Matrix $\left[R_{i j}^{a}\right]$

\begin{tabular}{|c|c|c|c|c|c|c|c|c|}
\hline & $\begin{array}{l}\operatorname{radius}(\mathrm{cm}) \\
\text { diffusion } \\
\text { coefficient } \\
\left(\mathrm{cm}^{2} / \mathrm{sec}\right)\end{array}$ & $\begin{array}{c}r_{1} \\
2.00 \times 10^{-7} \\
D_{1} \\
3.25 \times 10^{-3}\end{array}$ & $\begin{array}{c}r_{3} \\
4.06 \times 10^{-7} \\
D_{3} \\
7.97 \times 10^{-4}\end{array}$ & $\begin{array}{c}r_{5} \\
8.25 \times 10^{-7} \\
D_{5} \\
1.98 \times 10^{-4}\end{array}$ & $\begin{array}{c}r_{7} \\
1.68 \times 10^{-6} \\
D_{7} \\
5.05 \times 10^{-5}\end{array}$ & $\begin{array}{c}r_{9} \\
3.40 \times 10^{-6} \\
D_{9} \\
1.36 \times 10^{-5}\end{array}$ & $\begin{array}{c}r_{11} \\
6.90 \times 10^{-6} \\
D_{11} \\
3.99 \times 10^{-6}\end{array}$ & $\begin{array}{c}r_{13} \\
1.40 \times 10^{-5} \\
D_{13} \\
1.36 \times 10^{-6}\end{array}$ \\
\hline & 0 & 1.00000 & 1.00000 & 1.00000 & 1.00000 & 1.00000 & 1.00000 & 1.00000 \\
\hline decay & 1 & 0.00303 & 0.20724 & 0.59436 & 0.81727 & 0.91642 & 0.95993 & 0.97978 \\
\hline \multirow[t]{5}{*}{ stage } & 2 & 0.00001 & 0.05243 & 0.41516 & 0.72406 & 0.87402 & 0.93896 & 0.96852 \\
\hline & 3 & 0.00000 & 0.00336 & 0.20894 & 0.58992 & 0.80937 & 0.90789 & 0.95167 \\
\hline & 4 & 0.00000 & 0.00001 & 0.04365 & 0.34800 & 0.65509 & 0.82427 & 0.90568 \\
\hline & 5 & 0.00000 & 0.00000 & 0.00233 & 0.14250 & 0.46670 & 0.70975 & 0.83935 \\
\hline & 6 & 0.00000 & 0.00000 & 0.00001 & 0.03409 & 0.29 & 0.58 & 0.76410 \\
\hline \multicolumn{9}{|c|}{ Matrix $\left[R_{i j}^{b}\right]$} \\
\hline & $\begin{array}{c}\text { radius }(\mathrm{cm}) \\
\text { diffusion } \\
\text { coefficient } \\
\left(\mathrm{cm}^{2} / \mathrm{sec}\right)\end{array}$ & $\begin{array}{c}r_{2} \\
2.85 \times 20^{-7} \\
D_{2} \\
1.61 \times 10^{-3} \\
\end{array}$ & $\begin{array}{c}r_{4} \\
5.79 \times 10^{-7} \\
D_{4} \\
3.97 \times 10^{-4}\end{array}$ & $\begin{array}{c}r_{6} \\
1.18 \times 10^{-6} \\
D_{6} \\
9.96 \times 10^{-5}\end{array}$ & $\begin{array}{c}r_{8} \\
2.39 \times 10^{-6} \\
D_{8} \\
2.59 \times 10^{-5}\end{array}$ & $\begin{array}{c}r_{10} \\
4.85 \times 10^{-6} \\
D_{10} \\
7.25 \times 10^{-6} \\
\end{array}$ & $\begin{array}{c}r_{12} \\
9.85 \times 10^{-6} \\
D_{12} \\
2.28 \times 10^{-6}\end{array}$ & $\begin{array}{c}r_{14} \\
2.00 \times 10^{-5} \\
D_{14} \\
8.37 \times 10^{-7} \\
\end{array}$ \\
\hline & 0 & 1.00000 & 1.00000 & 1.00000 & 1.00000 & 1.00000 & 1.00000 & 1.00000 \\
\hline decay & 1 & 0.05126 & 0.41493 & 0.72636 & 0.87727 & 0.94241 & 0.97177 & 0.98525 \\
\hline \multirow[t]{5}{*}{ stage } & 2 & 0.00321 & 0.20871 & 0.59314 & 0.81432 & 0.91304 & 0.95651 & 0.97684 \\
\hline & 3 & 0.00001 & 0.05317 & 0.41359 & 0.71971 & 0.86888 & 0.93390 & 0.96408 \\
\hline & 4 & 0.00000 & 0.00283 & 0.17106 & 0.51799 & 0.75496 & 0.87217 & 0.92945 \\
\hline & 5 & 0.00000 & 0.00001 & 0.03548 & 0.30242 & 0.60514 & 0.78526 & 0.87842 \\
\hline & 6 & 0.00000 & 0.00000 & 0.00226 & 0.13692 & 0.45034 & 0.68868 & 0.81909 \\
\hline
\end{tabular}

where $Z_{j}{ }^{\text {obs }}$ is the measured value of $Z_{j}$ and $f_{j}{ }^{1}$, the first order approximation of $f_{j}$ is equated to $Z_{j}{ }^{\text {obs }}$.

Table 2 shows two response matrixes $\left[R_{i j}{ }^{a}\right]$ and $\left[R_{i j}{ }^{b}\right]$, which are calculated as follows. First, fourteen radius values $\left\{r_{k}\right\}$ are selected so as to divide the radius range between 0.002 and $0.2 \mu \mathrm{m}$ into thirteen subranges in logarithmically equal radius intervals. Then, fourteen values of the diffusion coefficients $\left\{D_{k}\right\}$ of the spherical particles with the radii $\left\{r_{k}\right\}$ are calculated. Next, for the six decay stages which are seen in Table 1, the values of $R_{i k}$ are calculated as follows:

0th decay stage

$$
R_{0 k}=1
$$

1st decay stage

$$
R_{1 k}=P\left(q, D_{k}\right), \quad q=4 / 100
$$

2nd decay stage

$$
R_{2 k}=P\left(q, D_{k}\right), \quad q=2 / 100
$$

3rd decay stage

$$
R_{3 k}=P\left(q, D_{k}\right), \quad q=2 / 200
$$

4th decay stage

$$
R_{4 k}=\left[P\left(q, D_{k}\right)\right]^{2}, \quad q=2 / 200
$$

5 th decay stage

$$
\begin{aligned}
R_{5 k}=\left[P\left(q_{1}, D_{k}\right)\right] & \times\left[P\left(q_{2}, D_{k}\right)\right], \\
q_{1} & =2 / 200, q_{2}=2 / 400
\end{aligned}
$$

6th decay stage

$$
\begin{aligned}
R_{6 k}=\left[P\left(q_{1}, D_{k}\right)\right]^{2} & \times\left[P\left(q_{2}, D_{k}\right)\right], \\
q_{1} & =1 / 200, q_{2}=1 / 400
\end{aligned}
$$

where $P\left(q, D_{k}\right) \equiv F\left(\Delta_{k}\right)$ of eq. (2) and $\Delta_{k} \equiv$ $\pi D_{k} L / 4 q . q$ is the flow rate (liters per minute) of aerosols passing through a thin tube.

Finally, we arrange the $R_{i k}$ values in the form of two response matrixes, $\left[R_{i j}{ }^{a}\right]$ and $\left[R_{i j}{ }^{b}\right]$ as follows:

$$
\begin{array}{r}
R_{i j}^{a}=R_{i k} \quad(i, j=0,1,2, \cdots, 6) \\
(k=1,3,5, \cdots, 13) . \\
R_{i j}^{b}=R_{i k} \quad(i, j=0,1,2, \cdots, 6) \\
(k=2,4,6, \cdots, 14) .
\end{array}
$$

For one series of decay measurements in the present work, six pairs of concentrations $\left(Z_{i}^{\mathrm{ex}}\right.$ and $\left.Z_{i}^{\mathrm{en}} ; i=1,2, \ldots, 6\right)$ are obtained, where suffix "ex" is for the concentration at the exit of the battery, "en" is for that at the entrance and " $i$ " is the order of the decay stages. Therefore, $Z_{i}$ obs of eq. (4) is given by $Z_{0}$ obs $=\left(\sum_{i=1}^{6} Z_{i}^{\text {en }}\right) / 6$ and $Z_{i}^{\mathrm{obs}}=Z_{0}{ }^{\mathrm{obs}} \times Z_{i}^{\mathrm{ex}} / Z_{i}^{\mathrm{en}},(i=1,2, \ldots, 6)$. Thus, linear equations are given as follows:

$$
\begin{aligned}
& {\left[\boldsymbol{R}_{i j}^{a}\right] \times\left\{f_{j}^{a}\right\}=\left\{\boldsymbol{Z}_{i}{ }^{\mathrm{obs}}\right\}} \\
& {\left[\boldsymbol{R}_{i j}{ }^{b}\right] \times\left\{f_{j}{ }^{b}\right\}=\left\{\boldsymbol{Z}_{i} \mathrm{obs}\right\} .}
\end{aligned}
$$

Then the approximated values of $f_{j}^{a}$ and $f_{j}^{b}$ are 
determined from eqs. (6) and (7) respectively by Ikebe's iterative method. By use of the $f_{j}$ values thus obtained, the spectral density values for fourteen tabular points are determined as follows:

$$
f\left(r_{k}\right)=\left\{\begin{array}{rr}
f_{0}^{a} / 2 \log \left(r_{1} / r_{2}\right) & \\
f_{j}^{a} / \log \left(r_{k+2} / r_{k}\right) & (j=1,2, \cdots, 6), \\
k=2 j \\
f_{j}{ }^{b} / \log \left(r_{k+2} / r_{k}\right) & (j=0,1, \cdots, 5), \\
f_{14}^{b} / 2 \log \left(r_{14} / r_{13}\right) & k=2 j+1 \\
(k=1,2, \cdots, 14) .
\end{array}\right.
$$

To test the numerical procedure, brief numerical experiments similar to those carried out by Ikebe (1972) were made for a few hypothetical distributions. Those numerical experiments show that 30 times of iteration cycle was proper to obtain a plausible distribution function. Also it was confirmed that the sensitivity of the estimated distribution function to errors in concentration measurement is similar to that which is given by Ikebe (1972); therefore the present method seems to be practically applicable. It should be mentioned, however, that there are some fears that the present method may give erroneous oscillatory values of spectral density for the radius range larger than $0.1 \mu \mathrm{m}$. For this reason, the values of spectral density presented in Fig. 6 are averaged over a radius range larger than $0.1 \mu \mathrm{m}$. Further detailed examinations of the present method are going to be carried out.

\section{References}

Ikebe, Y., 1972: Determination of the size distribution of polydisperse submicron aerosols by a response matrix method. PAGEOPH, 98, 197212.

Ingham, D. B., 1975: Diffusion of aerosols from a stream flowing through a cylindrical tube. Aerosol Sci., 6, 125-132.

Ito, T., 1976: An automatic Pollak counter improved for routine field operation. J. Meteor. Soc. Japan, 54, $81-90$.
Jaenicke, R., 1974: Size distribution of condensation nuclei in the NE trade wind regime off the African coast. Rech. Atmos., 8, 723-733.

Junge, C. and R. Jaenicke, 1971: New results in background aerosols studies from the Atlantic Expedition of the R.V. Meteor, Spring 1969. Aerosol Sci., 2, 305-314.

Junge, C. E., 1972: Our knowledge of the physicochemistry of aerosols in the undisturbed marine environment. J. Geoph. Res., 7\%, 5183-5200.

Metnieks, A. L. and L.W. Pollak, 1959: Instruction for use of photoelectric condensation nucleus counter. Geoph. Bull. No.16 the School of Cosmic Physics (Dublin Institute for Advanced Studies).

Misaki, M. Ikegai, M. and I. Kanazawa, 1975: Deformation of the size distribution of aerosol particles dispersing from land to ocean. J. Meteor. Soc. Japan, 53, 111-119.

Ohta, S. and T. Ito, 1973: Method of measurement of the background concentration of submicron aerosols and some results from the observations around the Ogasawara Islands and Marcus Island. Pap. Met. Geoph. 24, 111-137.

and —, 1974: Method of measurement of very low concentrations of submicron aerosols. Proc. of TECOMAP, WMO Technical Note No. 368, 387-393.

Pollak, L.W. and A. L. Metnieks, 1957a: On the determination of the diffusion coefficient of heterogeneous aerosols by the dynamic method. Geof. P. e Appl., 37, 183-190.

and 1957b: Intrinsic calibration of the photo-electric condensation nucleus counter model 1957 with convergent light beam, Technical (Scientific) Note No.9, Contract AF 61 (052)-26, Dublin Institute for Advanced Studies.

$\longrightarrow$ and $\longrightarrow$ 1957c: Photo-electric condensation nucleus counters of high precision for measuring low and very low concentrations of nuclei. Geof. P. e Appl., 37, 174-182.

and - 1961: Extinction in a photo-electric nucleus counter using adiabatic expansion of 1.21 pressure ratio achieved by increasing or decreasing the original pressure. Geof. P. e Appl., 49, 208-216.

Twomey, S., 1965: Size measurements of natural cloud nuclei. J. Rech. Atmos., 2, 113-119.

\section{北太平洋上のサブミクロンエーロゾルの粒径分布について}

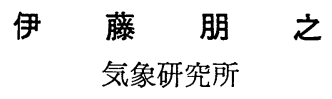

秋期の南鳥島 $\left(24^{\circ} \mathrm{N}, 154^{\circ} \mathrm{E}\right)$ 拉よび小笠原父島 $\left(27^{\circ} \mathrm{N}, 142^{\circ} \mathrm{E}\right)$ に物いて，サブミクロンエーロゾルの粒径分 布の観測を行なった。使用した装置は, 温度湿度条件が激しく変る野外に颃いても, 極低濃度のエーロゾルを高い精 度で測定できるよう工夫した 2 台のポラックカウンターと，4 種類の拡散管から成る自動装置である。観測した資料 
の解析の結果，エーロゾル濃度拉よび粒径分布は，気塊の起源によってはっきりと異なっていることがわかった。日 本列島を含む人間活動の盛んな地域からやってくる気塊は, 父島では大体 2,000 個/cc 程度, 南鳥島では 1,000 個/cc 程度の粒子をそれぞれ含んで拉り, 粒径分布の形は半径 0.02 ミクロンから 0.07 ミロンの範囲に峯を持つ幅の狭い分 布であった。これに対し, 中緯度海洋起源の気塊は, この海域のバックグラウンド值に相当する 250 個/cc 程度の粒 子を含み，その粒径分布は半径 0.02 ミクロンに峯を持つむしろ幅の広い分布を示した。

今回の観測結果は, 人間活動地域から污染が広がってきてバックグラウンド大気の中に拡散する末端地域での様子 を伝えるものである。運ばれてきた污染粒子はほとんど全て，自然の雲核と同程度の粒径を持つものであるため，人 工污染が中緯度海洋性気団の雲核のバックグラウンドに影響を与える可能性のあることを示すものである。 